\title{
Diagnostics of Sulfur Cement Properties
}

\author{
Mariusz Żółtowski ${ }^{1,{ }^{*}}$ Katarzyna Jeleniewicz ${ }^{1}$ \\ ${ }^{1}$ Warsaw University of Life Sciences - SGGW, 02-787 Nowoursynowska 166, Poland.
}

\begin{abstract}
In the presented research work the subject of investigation is the construction material under the name sulfur concrete (abbreviated as sulfur concrete). The paper presents a basic description of the material which is sulfur concrete, its composition and construction, the method of production and basic mechanical properties.
\end{abstract}

\section{Intorduction}

A multitude of innovative design solutions has forced progress and creation of new construction technologies while using innovative materials. This is why we have at our disposal a huge amount of Portland cements, mortars and concretes. Each of them is characterized by appropriate properties adapted to the place of later use of this material $[1,6,9]$.

The search for new materials, resistant to corrosion and useful especially for use in aggressive environments, has begun.

Sulfur-concrete may become such a material. The sulfur concrete can be described in its simplest form as a hot material prepared by adding organic materials to the heated sulfur, such as slag or sand. The new modified sulfur cement has been developed so that it can be used in construction as a corrosion-resistant material, with improved durability and strength.

The properties of sulfur concrete with other materials were compared, such as: mineral sulfur, sulfur polymer, mineral sulfur + gravel and ordinary concrete.

This provided grounds for determining the superiority of sulfur concrete over previously known building materials in terms of: resistance to solutions of organic and inorganic acids, salt solutions, resistance to salt mist, seawater, resistance to radiated radiation, energy, corpuscular $(\alpha, \beta)$, and neutron.

The outlined problem of testing selected properties of sulfur concrete in comparison with other building materials fully indicates the interesting features of the new construction material, useful in many possible construction applications.

\section{Sulfide as a construction material}

Sulfur is one of the most widespread elements, with a total of thirteenth resources on earth. Particularly large sulfur resources occur on the territory of the United States, which is why they are called sulfur tycoon. In the past, sulfur was the largest source of sulfur, but their reserves were decreasing. Currently, it is produced from various sources such as: recovery from acid gas, refining, sulfur ores and recovery from coal.

Acid electrolytes and rinsing resolve the caustic attack on PVC floors, column support, but these methods are not very effective. Materials such as potassium and sodium were produced, which supported the structure without worsening the damage. That is why the search for a material that could prevent corrosion and be a very good structural material, especially used in aggressive environments, was started.

\footnotetext{
*Corresponding author: mariusz_zoltowski@sggw.pl
} 
The sulfur concrete can be described in its simplest form as a hot-prepared material by adding organic materials such as slag or sand to heated sulfur. The new modified sulfur cement has been developed so that it can be used in the construction industry as an anticorrosive material, with improved durability and strength.

So, we started testing a new product on a large scale. Where the new material was used, corrosion repellency could be observed, both in acidic and alkaline conditions, while maintaining its strength properties. Confirmation of this theory were the positive results of tests carried out by the American Sulfur Institute. At the beginning of 1977, cooperating industrial plants initiated a control program testing sulfur concrete in corrosive industrial environments. The main goal of the program was to establish the principles of feasibility and usefulness of the new material on a large scale of applications and determine the final properties of the material in a corrosive environment. The results were to show the useful potential of the material in corrosive environments where other materials were destroyed. An example here may be: corrosive electrolytes, acids, salts.

It was this technology of sulfur-concrete product that came to Poland. Hitherto used technologies of hazardous waste disposal consisted in neutralization and chemical treatment, followed by stabilization in various types of binders: Portland cement, pozzolanic cement, binding materials, paraffins and synthetic organic polymers, with Portland cement being the most commonly used for this purpose.

Not all hazardous waste is efficient. New, better solutions are constantly being sought $[3,4,5]$.

The technology over which OBR PS "Siarkopol" works together with "Ekostrad" Kielce concerns the use of polymeric sulfur - sulfur cement as a material stabilizing material in the physical process, containing heavy metals, especially mercury and arsenic. Solid waste cemented with sulfur cement can be safely stored or used as elements of insulation barriers and sulfur concrete constructions, among others for construction of landfills.

These studies have confirmed that sulfur cement is better for this purpose than other binders. The stabilized waste obtained in this way is characterized by generally very low leachability of harmful components as well as mechanical strength and chemical durability, making it possible to make construction elements of them for special purposes.

\section{Properties and application of sulfurness}

Sulfur concrete as a material was developed in the seventies and eighties of the last century. Its constituent elements are: sulfur and aggregate. Plain concrete consists of cement, water and aggregate. The binding components are cement and water. In the case of sulfur concrete, sulfur is the binding element. The sulfur is chemically modified, which results in very good binding properties. No cement or water is needed. In order to obtain sulfur concrete, the sulfur and aggregates should be combined with each other. This happens at a temperature of about 140 degrees Celsius [7,8].

The binding process of this material occurs as a result of the mixture cooling. This concrete is very similar to ordinary, but its properties are slightly different. Sulfur itself is a by-product in many processes, mainly refining fuels, gases and coal.

The most important property of sulfur concrete is very high resistance to chemical corrosion. It is resistant to acids, salts and bases, as well as petroleum oils, solvents and other aggressive substances. Another important property is high mechanical strength and abrasion resistance. It is much higher than ordinary concrete. The structure of sulfur concrete has a very low porosity, and due to its hydrophobic properties, the material contained in the concrete does not rinse.

These properties result from the fact that the hardening of sulfur concrete is a physical process, unlike ordinary concrete, in the case of which we are dealing with a chemical process. The first feature is the high hardening rate, which lasts 24 hours, although in 
practice it takes 3-4 hours. Another property is the possibility of recycling. At the end of the useful life, the sulfur concrete can be crushed, melted and reused.

Presenting experience related to the practical application of this material, it should be mentioned that it is used in the United States, Canada and South America. Sulfur concrete has already gained widespread use there. The first of them are plants related to the processing of metal ores. In copper and zinc processing plants we deal with a very aggressive acidic environment $[1,8]$.

The second area of application are floors in plants that deal with a highly acidic environment. Examples are fertilizer manufacturers and battery companies. In South America, sulfur concrete is used as a prefabricated element. It can be used to produce tanks for chemical products. In addition, it can be used in the production of sewerage and drainage pipes.

Very good experience gained from those countries guarantee equally effective use of sulfur concrete in Europe, eg the production of precast concrete elements has the advantage over using traditional concrete that allows you to quickly obtain full properties. Some elements can be used in road engineering as barriers or as structural elements. An additional possibility created by the production of sulfur concrete is the utilization of waste. Waste from a variety of industrial activities can be used as fillers. Examples of waste that can be used are metal waste, asbestos and organic waste. Remember that sulfur itself is also waste.

The last way to use this type of concrete is to use it for road construction in countries with very cold climates where there are problems with the use of asphalt and ordinary concrete. Sulfur concrete does not contain water. The possibilities of using this material are therefore huge. It can be assumed that also in our country, sulfur concrete will soon find the right application.

\section{Description of modified sulfur cement}

The preparation of the resisting corrosion of sulfur concrete has been changed along with the development of modified sulfur cements that have overcome the problems of instability and corrosion. Prepared dicyclopcntadiene and cyclopentadiene in a sealed oven from 6 to 12 hours at $145^{\circ} \mathrm{C}$. The heated sulfur acquires a liquid consistency in which it can be used.

The unmodified sulfur, cooling from the liquid state, crystallizes into a homogeneous crystalline form and, cooling below $95.5^{\circ} \mathrm{C}$, takes on a more dense, lighter and smaller volume form. After complete cooling, the sulfur cement does not undergo immediate transformation. The resulting sulfur concrete is more durable.

Modification of sulfur cement is patented by the American Trade Department, and patent rights are held by the Chemical Company of Houston in Texas, which is precisely introducing cement on the market [8].

Modified sulfur concrete is a hot-prepared material, mixing cement and admixtures at a temperature of $125^{\circ} \mathrm{C}$ to $150^{\circ} \mathrm{C}$. The resulting product is cast into a form giving the desired shape and then it is cooled. This process is a thermal process that can be repeated when necessary.

In construction, more and more often a good quality construction material containing components for combating corrosion is required. The sulfur concrete must be clean, have low absorption, and dried should contain less than $0.25 \%$ water. If corrosion is caused by salt, quartz, limestone, we use rounded gravel. Rough surfaces give a better bond for a sulfur binder than polished surfaces of rounded gravels.

The cement requirements for the preparation of sulfur concrete are such that when we use more sulfur, we add less binder, and the mechanical properties remain the same. The mix should be designed according to the aggressiveness of the environment in which it will be used. 


\section{Industrial use of sulfur concrete}

Sulfur concrete is prepared hot by mixing modified sulfur cement and additives. It is recommended to use a mixer that will keep the mixture at the right temperature.

Testing the quality of sulfur concrete consists in inserting ready samples into aggressive environments together with Portland cement and comparing the results.

The sulfur concrete is poured hot and must be cooled to the point where it begins to solidify. Under normal conditions, it takes approximately 30 minutes. Insulated tanks can be used to transport sulfur concrete from the mixer to the casting. A vibrating probe is used to densify the sulfur mixture, especially when used in large quantities.

Sulfur concrete is used in sulfuric acid and ammonium sulphate plants in sewers and sumps (Fig. 1), where despite contact with hot sulfuric acid (concentration up to 98\%) there are no problems. It was used both as a monolith and as a protective coating on existing concrete.

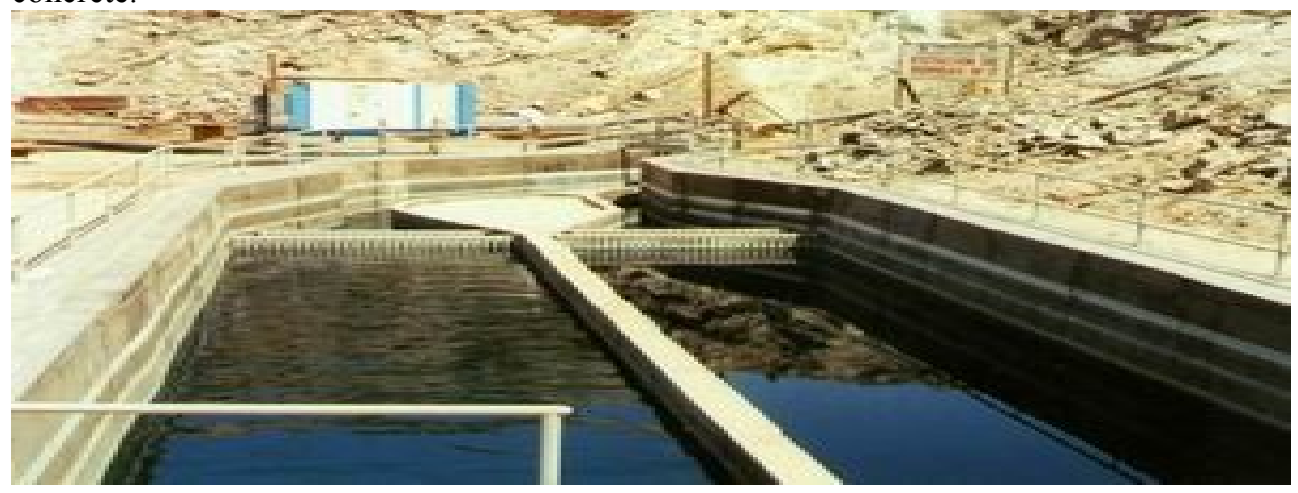

Fig. 1. Sulfur concrete used in the construction of sewers and drains.

Sulfur concrete floors have also been installed in many rooms with electrolytic baths, showing exceptional functionality there (Fig. 2).

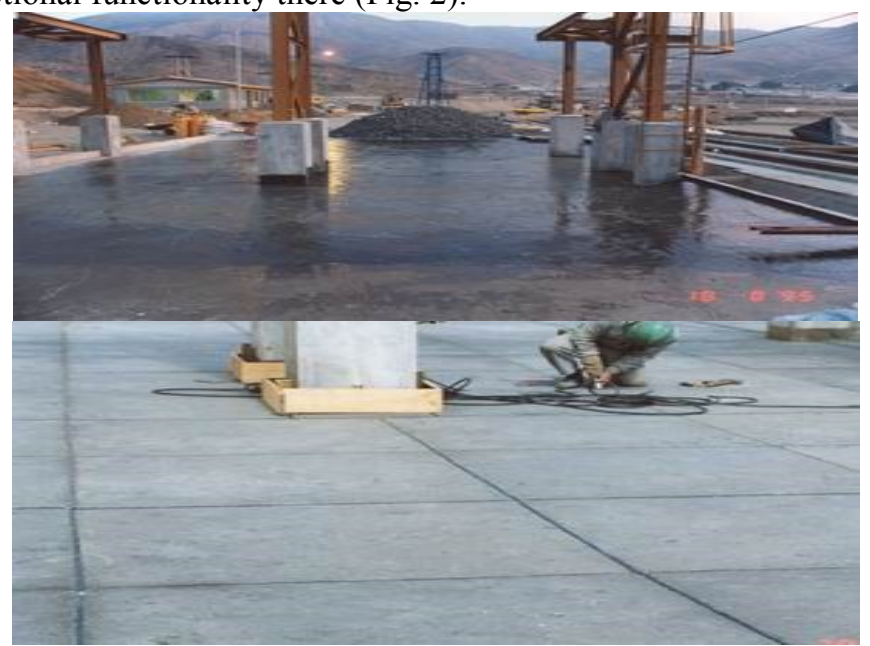

Fig. 2. Floors made of sulfur concrete.

Field tests with the performance of road pavements have been successfully carried out using traditional machines for asphalt pavement construction, equipped with heated, vibrating leveling boards (no need to roll for compaction) and standard machines for building concrete pavements with pre-heating of leveling boards. Road elements, such as 
central barriers, road signs and traffic lights, curbs, railroad crossings - all of this type of sulfur concrete products are successfully used in Calgary. Such elements are shown in Fig.3.

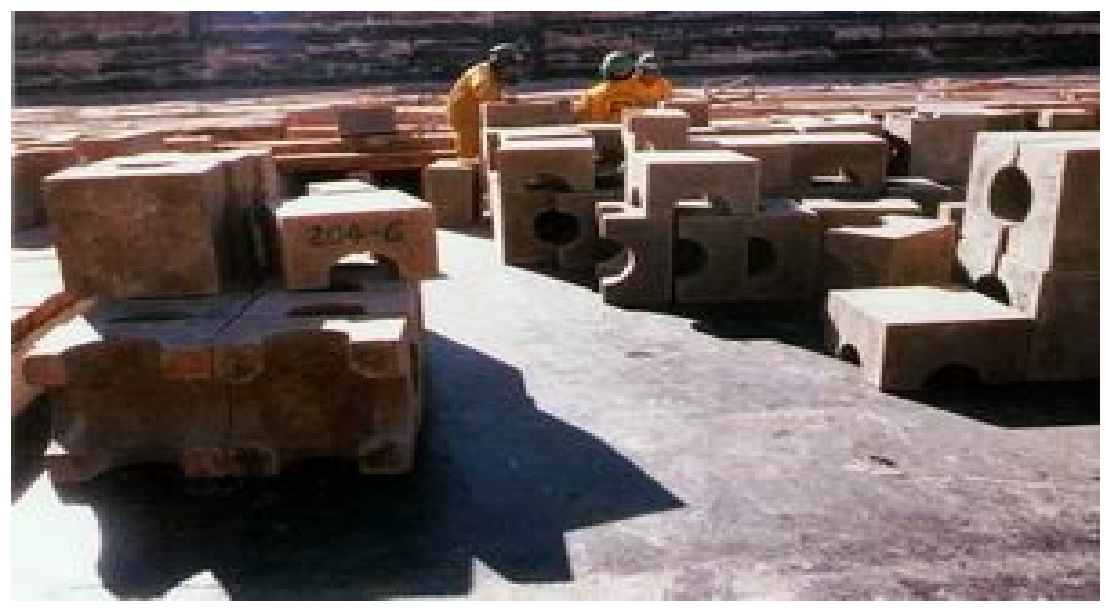

Fig. 3. Road elements, such as central barriers made of sulfur concrete.

Runways and airport plates, attempts to repair airport plates using sulfur concrete were very encouraging - quick consolidation is a very important factor here.

Floors in food processing plants are exposed to highly corrosive conditions, not only organic acids that can soak into concrete surfaces, but also cleaning and disinfecting agents used daily for sanitary reasons. In 1987, concrete was approved for use in food processing plants in both Canada and the United States. Inspectors from Agriculture Canada encouraged its use to solve the corrosion problems that occur with ordinary concrete and concrete-liner combinations.

\section{Sulfur production in Poland}

In Poland, MARBET in Tarnobrzeg has recently been engaged in the production of sulfur concrete. The obtained sulfur concrete (SULTECH®) allows stabilization of a number of hazardous wastes containing barium, zinc, chromium, mercury, heavy metals and asbestos (confirmed by tests of research units) - Table 1.

The resulting sulfur concrete containing stabilized asbestos is characterized by very good parameters (confirmed by ITB, PZH), such as:

- high strength of products;

- resistance to acids, seawater, sewage;

- high frost resistance;

- lack of absorbability;

- no electrical conductivity (perfect dielectric);

- short time of forming and obtaining nominal strength;

- the possibility of recycling products (thermoplastic).

In the years 1999-2001, many industrial applications using sulfur polymer were developed at MARBET. It was also possible to use SULCEM ${ }^{\circledR}$ polymer for stabilization of waste. This process is particularly useful in the case of stabilization of waste containing heavy metals such as cadmium, chromium, arsenic, barium salts, salts of other metals, ashes from waste incineration plants, as well as asbestos-containing elements. Past effects.

We offer our own original technical and technological solutions proprietary to the process of recovery of hazardous solid industrial waste by stabilization using sulfur polymer in SULBET ${ }^{\circledR}$ polymer concrete. 
Table 1. Characteristics of sulfur cement.

\begin{tabular}{|c|l|c|c|}
\hline \multicolumn{4}{|c}{$\begin{array}{c}\text { COMPARISON OF PHYSICAL AND MECHANICAL PROPERTIES OF } \\
\text { SULUR CONCRETE AND TRADICIONAL CONCRETE }\end{array}$} \\
\hline Lp. & Properties & Sulfur concrete & $\begin{array}{c}\text { Tradicional } \\
\text { concrete }\end{array}$ \\
\hline 1. & Density & $2.4 \mathrm{~g} / \mathrm{cm}^{3}$ & $2.2 \mathrm{~g} / \mathrm{cm}^{3}$ \\
\hline 2. & Compressive strenght & $60-115 \mathrm{MPa}$ & $15-60 \mathrm{MPa}$ \\
\hline 3. & Flexural strenght & $10-16 \mathrm{MPa}$ & $6-7 \mathrm{MPa}$ \\
\hline 4. & Young's module & $40-65 \mathrm{GPa}$ & $25-28 \mathrm{GPa}$ \\
\hline 5. & Shrinkage & $0.5-1.0 \mathrm{~mm} / \mathrm{m} *$ & $0,6 \mathrm{~mm} / \mathrm{m}$ \\
\hline 6. & Thermal expansion & $10-30 \cdot 10^{-6} 1 /{ }^{\circ} \mathrm{C}$ & $8-10 \cdot 10^{-6} 1 /{ }^{\circ} \mathrm{C}$ \\
\hline 7. & Thermal conductivity & $0.4-2 \mathrm{~W} / \mathrm{m}^{\circ} \mathrm{C}$ & $1,4-3,6 \mathrm{~W} / \mathrm{m}^{\circ} \mathrm{C}$ \\
\hline 9. & Impregnability & $0-1 \%$ & $5 \%$ \\
\hline 10. & Frost rezistance & $\mathrm{F}>500$ & $\mathrm{~F} 50$ \\
\hline 11. & Time required to form an element & $0.1-0.4 \mathrm{~h}$ & $48 \mathrm{~h}$ \\
\hline 12. & Resistance to aggressive environment & $10-15 \%$ & $20-30 \%$ \\
\hline 13. & $\begin{array}{l}\text { The proportion of binding material in the } \\
\text { finished concrete }\end{array}$ & & \\
\hline
\end{tabular}

This method, due to the good mechanical and physicochemical properties of the produced polymer concrete (high resistance to acids and salts), can be widely used in waste recovery, e.g. for the production of:

- concrete elements used for lifting shafts;

- flood protection (SULTECH SYSTEM NOE®), for reinforcing soils preventing landslides as well as for the production of pipes with chemical resistance, etc. elements embedded in the ground,

- elements of manholes and covers with finial for telecommunications,

- concrete elements for road construction: road plates, openwork plates intended for car parks, culverts and road borders, linear drainage, sewer and sediment manholes ;;

- weights for flooded pipelines and cables of railway traction and weights for automatic washing machines.

The main advantages of the SULBET ${ }^{\circledR}$ polymer concrete produced include:

1. technological features:

- the possibility of recycling products in the future (thermoplastic),

- short time of concrete elements curing and reaching their nominal strength (table 2).

2. functional features:

- very good mechanical properties (high compression and bending strength) exceeding the analogous Portland concretes (ITB test results, table 2),

- resistance to aggressive media: acids, salts, oils, municipal sewage, sea water (ITB),

- excellent corrosion resistance (ITB tests),

- tightness and very high frost resistance (ITB tests, table 1), 
- very low absorbability (table 1),

- a comparable coefficient of linear expansion with concrete based on Portland cement (Table 1),

- possibility of making reinforced concrete elements - SULBET ${ }^{\circledR}$ polymer concrete has a higher binding strength to reinforcing steel than Portland concrete and protects it against corrosion (ITB tests),

- it can be used to stabilize hazardous waste (eg ashes from waste incineration plants) without deteriorating its properties (ITB research).

Table 2. Benefits resulting from the replacement of conventional concretes with sulfur concrete.

\begin{tabular}{|c|c|c|c|}
\hline Infastructure & Application & Important properties & $\begin{array}{c}\text { The advantages of } \\
\text { using sulfur } \\
\text { concrete }\end{array}$ \\
\hline Sewage & $\begin{array}{l}\text { sewage pipes, manholes, } \\
\text { processing plants }\end{array}$ & $\begin{array}{l}\text { strength, durability, } \\
\text { resistance to corrosion, } \\
\text { impermeability, } \\
\text { not leaching }\end{array}$ & $\begin{array}{c}\text { - increased } \\
\text { durability } \\
\text { - sewage pipes do } \\
\text { not require } \\
\text { protective lining } \\
\text { - lower cost }\end{array}$ \\
\hline Solid waste & $\begin{array}{c}\text { tanks, } \\
\text { sheath (hermetic) }\end{array}$ & $\begin{array}{l}\text { strength, durability, } \\
\text { resistance to corrosion, } \\
\text { impermeability, } \\
\text { not leaching }\end{array}$ & $\begin{array}{c}\text { - increased } \\
\text { durability } \\
\text { - longer life } \\
\text { - lower cost in terms } \\
\text { of the utility cycle } \\
\end{array}$ \\
\hline $\begin{array}{l}\text { Radioactive } \\
\text { waste }\end{array}$ & burials & $\begin{array}{l}\text { durability, resistance and } \\
\text { radiopacity, }\end{array}$ & $\begin{array}{l}\text { - higher resistance } \\
\text { and impermeability } \\
\text { of radiation than } \\
\text { lead }\end{array}$ \\
\hline Transport & $\begin{array}{l}\text { bridges, } \\
\text { road surfaces }\end{array}$ & $\begin{array}{c}\text { durability, } \\
\text { impermeability, quick } \\
\text { consolidation, durability }\end{array}$ & $\begin{array}{c}\text { - increased } \\
\text { durability } \\
\text { - quick } \\
\text { consolidation } \\
\end{array}$ \\
\hline Agriculture & $\begin{array}{l}\text { animal pens, sewers, } \\
\text { troughs }\end{array}$ & $\begin{array}{l}\text { resistance to corrosion, } \\
\text { impermeability, } \\
\text { strength, } \\
\text { durability } \\
\end{array}$ & $\begin{array}{c}\text { - hygiene } \\
\text { improvement } \\
\text { - lower cost } \\
\text { - ease of cleaning } \\
\end{array}$ \\
\hline Chemical Works & $\begin{array}{l}\text { floors, sumps, tanks, } \\
\text { sewers }\end{array}$ & $\begin{array}{l}\text { corrosion resistance, } \\
\text { imperviousness strength }\end{array}$ & $\begin{array}{l}\text { - durability } \\
\text { - quick } \\
\text { consolidation }\end{array}$ \\
\hline Food industry & floors, walls & $\begin{array}{c}\text { resistance to corrosion, } \\
\text { impermeability, } \\
\text { durability }\end{array}$ & $\begin{array}{l}\text { - ease of cleaning } \\
\text { - quick } \\
\text { consolidation } \\
\text { - shortens breaks at } \\
\text { work }\end{array}$ \\
\hline $\begin{array}{c}\text { Marine } \\
\text { environment }\end{array}$ & $\begin{array}{c}\text { breakwaters, buoys, } \\
\text { docks, wharfs for barges }\end{array}$ & $\begin{array}{c}\text { corrosion resistance, } \\
\text { durability, } \\
\text { impermeability, } \\
\text { durability }\end{array}$ & $\begin{array}{l}\text { - durability } \\
\text { - ease of repair or } \\
\text { renewal }\end{array}$ \\
\hline Water & pipes, tanks, pools & $\begin{array}{c}\text { corrosion resistance, } \\
\text { durability, } \\
\text { impermeability }\end{array}$ & $\begin{array}{l}\text { - durability } \\
\text { - longer life } \\
\text { - lower cost }\end{array}$ \\
\hline
\end{tabular}




\section{Use of sulfur concrete for road repair}

The subject of the invention is a method for producing mixtures based on a sulfur binder for road repairs, used as a construction material with increased resistance to dynamic loads, useful especially in difficult weather conditions.

The method for producing sulfur-based binder mixes for road repairs containing sulfur and / or sulfuric polymer is characterized in that the sulfur and / or sulfur polymer is heated until it reaches a liquid or semi-liquid state, after which it is sprayed, preferably under the effect of the overpressure, whereby mineral aggregate and metal filler in the form of preferably short metal fibers are introduced into the so formed mist for the time of complete coating of the mineral aggregate and the metal filler with sulfur and / or sulfur polymer, and then cooled to ambient temperature.

\section{Summary}

The content of this work discusses selected issues related to the new building material, which is sulfur concrete. The outlined problem of testing selected properties of sulfur concrete in comparison with other building materials fully indicates the interesting features of the new construction material, useful in many possible construction applications.

Even cautious inference supported by the study of this work indicates that the use of sulfur concrete in environments exposed to corrosion is technically and technologically feasible. This material shows excellent mechanical properties, much better than other materials, e.g. Portland cement.

A certain obstacle in the use of sulfur concrete, however, is the flammability of sulfur and its low melting point. Under the influence of fire, the sulfur binder in the concrete burns (however, immediately after removing the fire it goes off immediately). Sulfur concrete also softens when heated, which is why it is not suitable for constructing structures working under load.

\section{References}

1. I. Biczok, Concrete corrosion and concrete protection (Budapest, 1964)

2. R.T. Conley, M. Dekker, Thermal stability of polymers (New York 1970)

3. F. Lea, The chemistry of cement and concrete (London, 1970)

4. W. Lucas, Cement and concrete research FCD Vol. 5, (1975)

5. M.V. Moskvin, Korozja betonu (Moscow 1952)

6. R. Shalon, M. Raphael, Sulfur concrete proprieties JACI Vol. 55 (1955)

7. T. Sikorski, Podstawy chemii i technologii polimerów PWN (Warszawa 1985)

8. W. Schnabel, Polymer degradation Akademie-Verlag (Berlin 1981)

9. M. Żółtowski, Właściwości betonu siarkowego w środowisku zasadowym UWM (Olsztyn 2004) 